\title{
Designing Number Learning Applications and Early Childhood Mathematics Calculations
}

\author{
Nofri Wandi Al Hafiz \\ Kuantan Singingi Islamic University \\ Kuantan Singingi, Indonesian \\ wandie.88one@gmail.com
}

\author{
Helpi Nopriandi \\ Kuantan Singingi Islamic University \\ Kuantan Singingi, Indonesian \\ helpinopriandi83@gmail.com
}

\begin{abstract}
The progress and development of technology in the current era is very rapid, this is seen from any community that uses the technology, even now technology has entered the world of education in terms of the teaching and learning process, with the current learning and teaching process which still focuses teachers as a material giver, it will make the learning and teaching experience of students become monotonous and unattractive, attracting students to become bored and less fun with math lessons that use a lot of thoughts, unless this teacher can help learn interesting classes then will make the class enthusiastic, to help teachers in the teaching process, it is necessary to make an application that can help teachers to make students interested in learning mathematics.
\end{abstract}

\section{Keywords - Mathematics, Learning Applications, Multimedia}

\section{INTRODUCTION}

With the process of learning and teaching at this time which still focuses the teacher as the material giver, it will make the learning and teaching experience of students become monotonous and less attractive so that students become bored and lack enthusiasm especially with mathematics lessons that use a lot of thoughts, unless the teacher can bring the class atmosphere to be interesting it will make the class atmosphere become excited.

The problem that actually tends to appear frequently in the school system at this time is that the distribution of textbooks that are not long lasting is often torn by students and makes students difficult to learn.

Along with the times, the writer tries to make new ways in the teaching and learning process, by providing an interesting method of delivering material and learning processes, many schools nowadays have applied information technology in the form of using laptops and focus in delivering material in the form of color images colorful, so that it can make students become excited and not saturated, for that we are here trying to make a special application to help teachers in delivering the material which can be a learning game specifically for math teachers in introducing numbers and teaching students how to do addition, subtraction, multiplication and division quickly.

\section{Literature REVIEW}

Learning is a process that aims to develop self-potential in students and realize the process of providing better information. This learning aims to develop personality, intelligence and educate participants to have noble character, be able to control themselves and have skills. Learning is better known as the word education. This learning begins with parents when the child is a baby and will last a lifetime.

Learning or education when babies are carried out by parents in very simple ways, education is not only in a formal education but also in non-formal education to someone or more than one person both together or individually. School is one of the facilities that provide benefits for students where learning is carried out in schools capable of socializing students to educate them for a better generation.

According to Wandah Wibawanto (2013) expressing game ideas is an idea about the game that will be made, the game idea includes the type or type of game, the character used, as well as / story board of the game, and the details that are in our shadow before making the game. 
Humans have 2 memory systems, namely longterm memory and short-term memory. The idea of making games flashes like that in our minds in short-term memory, so we easily forget the idea.

Still obeying Wandah Wibawanto (2013) stated that nowadays there are so many games we find, be it PC games, game consoles, HP games and Flash games, game classifications are based on: Board Games, Arcade, Action, Shooting, Fighting, Racing, Simulation, RTS (Real Time Strategy, RPG (Role Playing Game), MMO (Massive Multiplayer Online).

According to Rickman Roedavan (Unity, 2018) explained that the development of game engines in the early 80s, almost all games were built using intermediate level programming codes such as C. All interaction logic in the game was compiled using programming logic specific to one game title. So to build two different game titles, two of the same and repeated activities will be needed.

explained that the development of game engines in the early $80 \mathrm{~s}$, almost all games were built using intermediate level programming codes such as C. All the interaction logic in the game was compiled using programming logic specific to one game title. So to build two different game titles, two of the same and repeated activities will be needed.

\section{Proposed METHOD}

The research methodology includes the sequences carried out in a study. The research methodology aims to make the research more conceptual, structured and directed, so that each stage will be able to see its achievements in accordance with the expected goals of the study..

The method of this research can be described by the author in the form of flowcharts like this below :

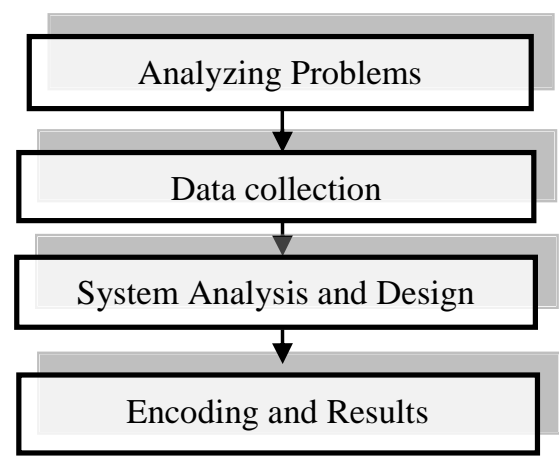

Figure 3.1 research methodology

\subsection{Research sites}

014 State Elementary School (SD) Binjai Island was established in 1980 and was operated in the same year, the year of the year 1981, the decree 0220 / C / 1981, on April 7, 1981, the issuer of the Decree was signed by KPKN Rengat. Kuantan Mudik Elementary School 014 is located on Jl. Natural Hot Water No.003 Hamlet III RW III RT III Pulau Binjai Village Kuantan Mudik District, Kuantan Singingi Regency. The level of accreditation A, SK accreditation number 362 / BAP-SM / KP-09 / X / 2011, October 25, 2011, status of land and property rights. The climbing structure at Kuantan Mudik Elementary School is in Kepalai by Mr Naswim, A.Ma.Pd with a total of 100 students and 13 teachers teaching..

\subsection{System planning}

To build a system requires good preparation and planning, clear goals and repeated experiments to get maximum results. System design is an attempt by agencies or companies to start having a new system.

The purpose of system design is to provide an overall picture to the user about the new system. System design generally identifies components of information systems designed specifically for computer programming and other related experts who will implement the system.

The design of this system includes the system flow chart, system design and manufacture. The stages in system design are:

System design (system flow chart) is described in the form of Usecase diagram. Designing input (input), with the design of the intended input to facilitate data entry.

Design process.

Use Case Diagaram is a construction to describe the relationships that occur between actors and activities contained in the application. The purpose of modeling Use Case is to define the functional and operational requirements of the system by defining the scenario of the use of the system to be built. In accordance with the user's task in playing this game, the user can interact directly with the educational game by selecting the game sub menu that is available in each environment in this game, the interactions that can be done by the user include :

After clicking start it will enter the menu and the player is free to choose which object he wants. 
Users can choose material or educational games that match the selected object.

When an object is selected it will bring up the selected material or game.

From the results of the analysis, the use case diagram for the mathematics education game application can be seen in Figure 3.1 Use Case The following diagram:

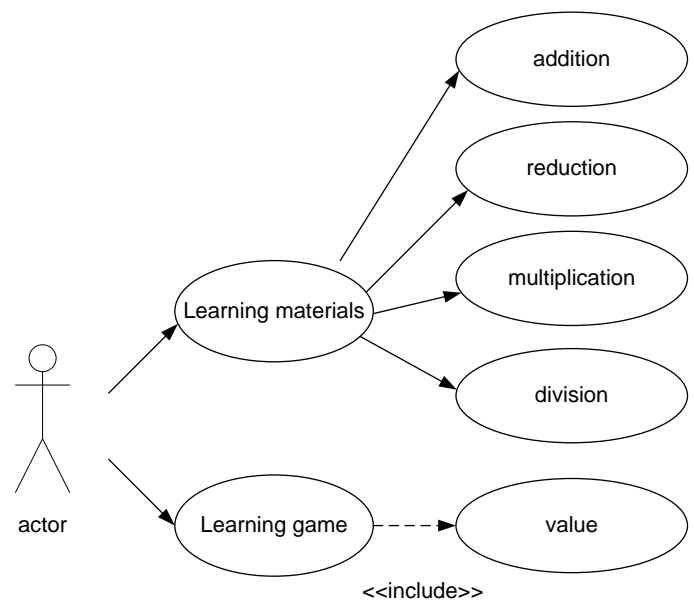

Figure 3.2. Use Case Diagram

UML Modeling Activity diagram is a depiction of the flow of activity in a designed system.

The following figure illustrates the acivity diagramof mathematics learning material:

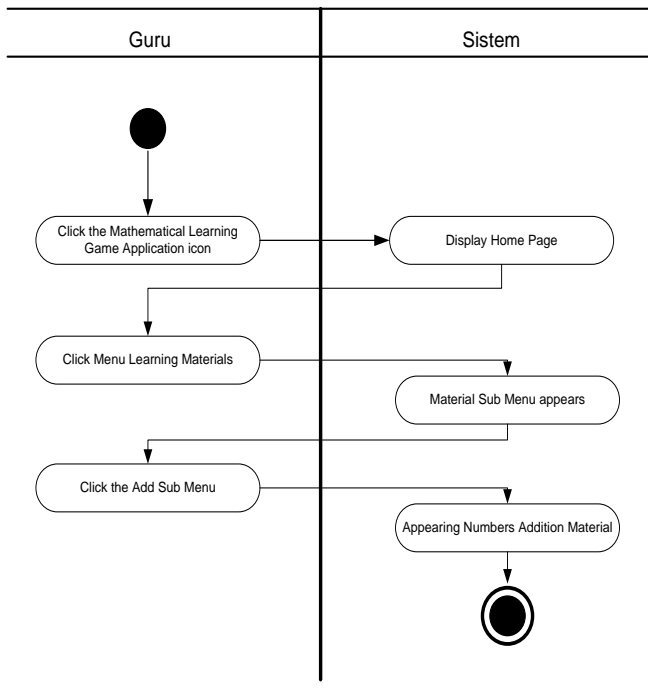

Figure 3.3 Diagram Activity Sub number addition sub menu

Based on Figure 3.2 Proposed Activity Diagram there are:
1 intial node as bodyguard object.

1 actor who can carry out activities namely Teacher.

6 (six) action states that start with the Click on Educational Game Icon, Display Home Page, Click Menu Learning Material, Show Page Sum Material Menu, Click Addition, Display Addition Material. When the sidah is finished, exit.

1 activity final node explains that the object was stopped.

The following picture illustrates the activity diagram of the value education game:

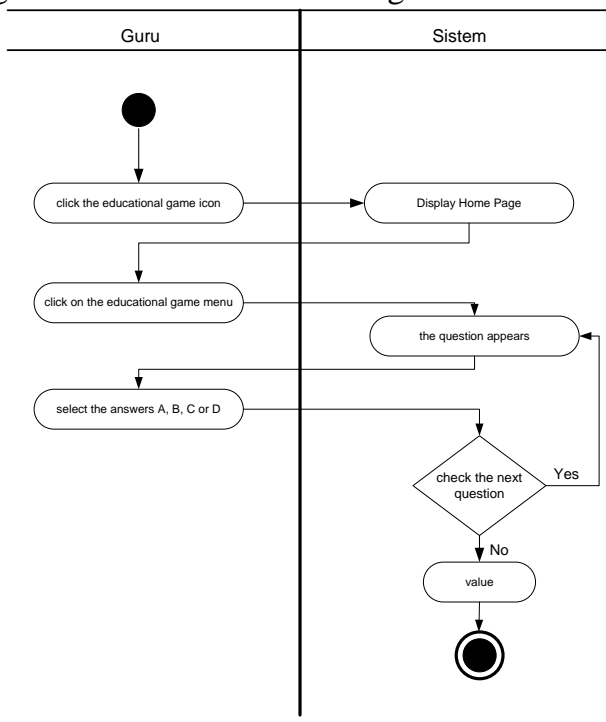

Figure 3.4 Activity diagram value

The following picture illustrates the educational game Sequence diagram select the addition menu:

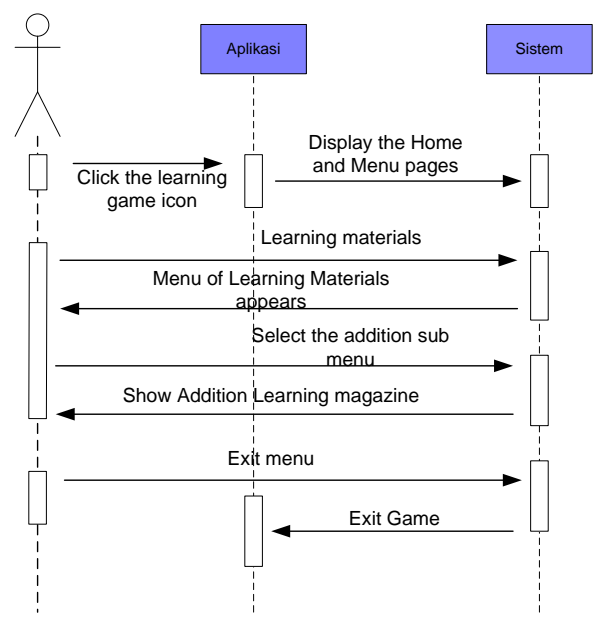

Figure 3.5 Sequence Diagram Select the Add Menu 


\section{RESULT AND DISCUSSION}

\subsection{Output Design}

The design of output can be used to produce information. The design of this output will display the output data or reports that are desired to be ready to do printing with data sources. The output display form is as described below:

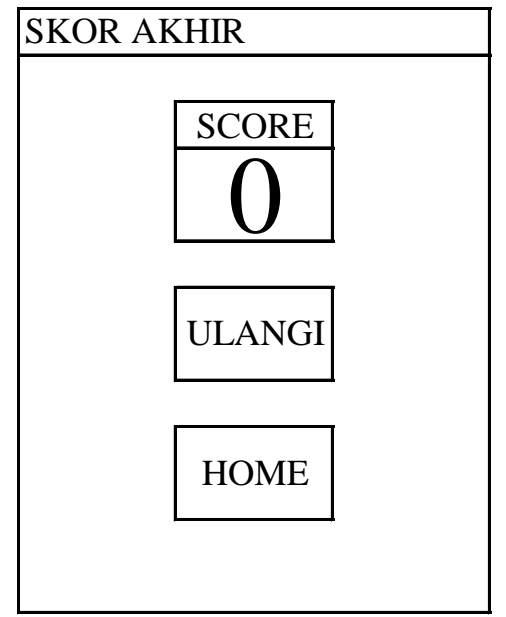

Figure 36 Output Design

Designing the Main Menu

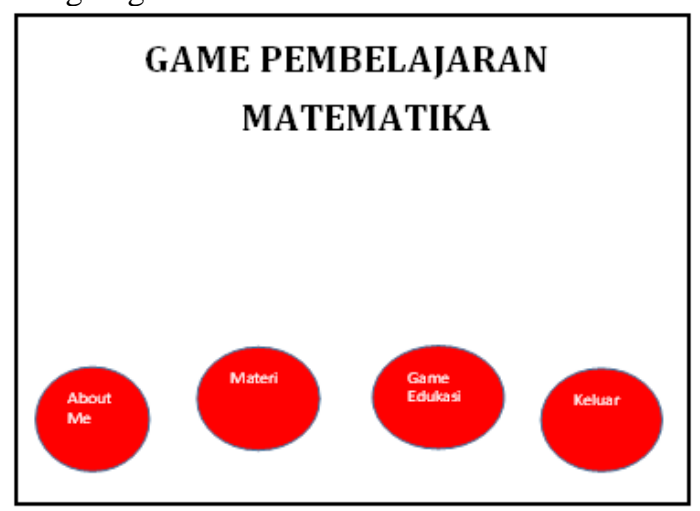

Figure 3.7 Draft Main Menu

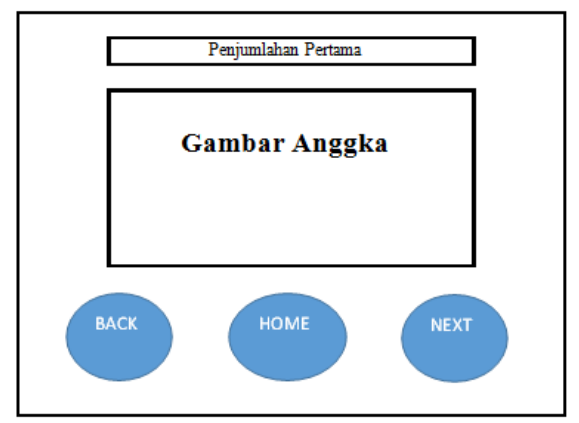

Figure 3.8 Draft Number Add Form

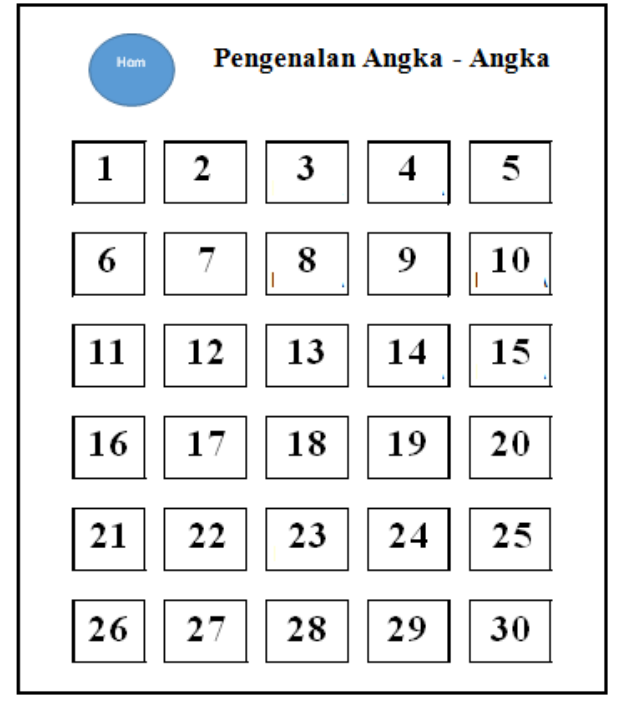

Figure 3.9 Number Recognition

At this stage the results of the interface design are implemented into the application system that is built using multimedia software, which is listed in the image below and for the next interface can be seen in the following figure:

The main menu is the initial display (main menu) of the Muslim children's educational game in which there are several menus. So every time we enter the Muslim children's educational game, this main menu will appear.

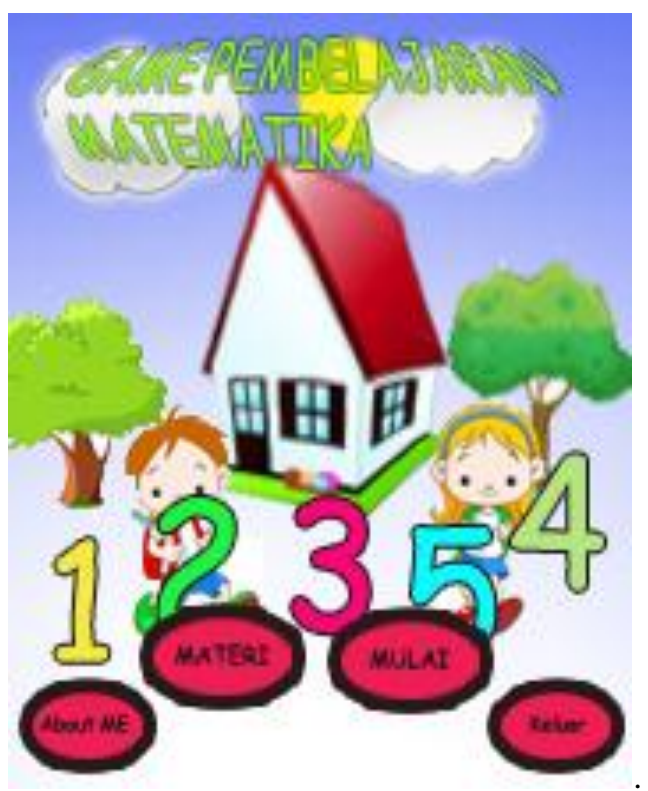

Figure 4.1 Main Menu 
then on the next selection menu to start learning, we click on the material menu, the numbers will appear. as in the picture below:

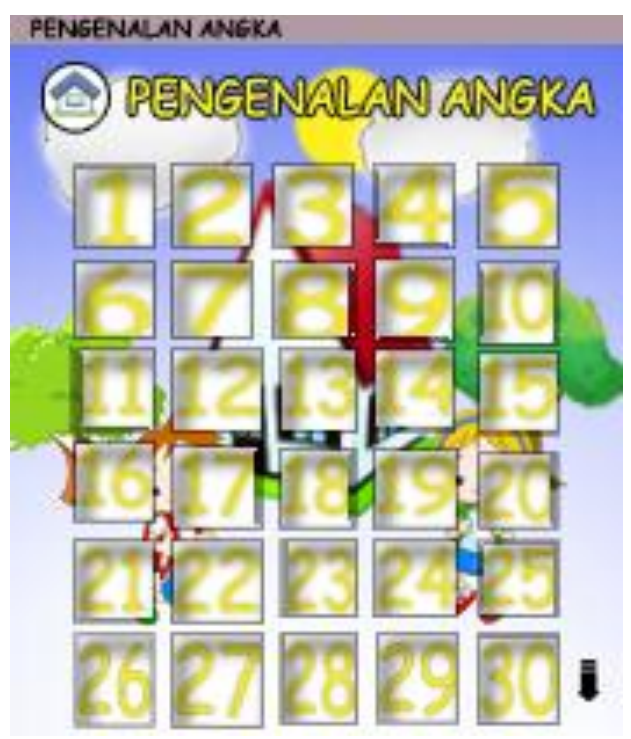

Figure 4.2 Number recognition

in this menu, the user can also click on the number on the screen and the application will respond by issuing a sound and mentioning the selected number.

as in the picture below:

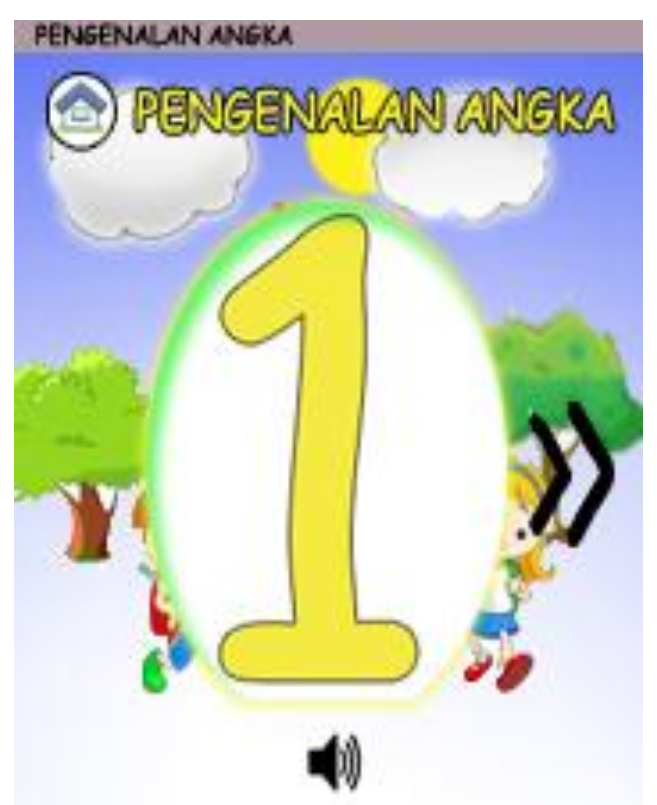

Fugure 4.3 Single digit display from the trial of application use in the research location, namely the 014 pulau binjai public elementary school, then after students in the learning material use multimedia games based on learning games, subject teachers who use this application find it easy to teach students, this is because at this children are more technologically friendly and are very interested in this and the learning by using this application by teachers is considered very petrified.

what's more in mathematical material where children are very little interested in this material.

\section{Conclusionand Suggestion}

Based on the results of the implementation of this mathematics learning game, it can be concluded that this math learning game can help teachers and early childhood especially elementary school children in class 1 change conventional learning methods into simulation learning ways with media games and facilitate early childhood to learn about the types of numbers that are equipped with attractive color and character applications.

for the value of the assessment carried out by the teacher, it can be seen in the following table::

list of values for mathematics class 1 grade 014 elementary school Pulau Binjai number recognition and addition material in 2018.

\begin{tabular}{|c|l|c|c|c|}
\hline No. & \multicolumn{1}{|c|}{ Nama Siswa } & $\begin{array}{c}\text { Nilai } \\
\text { Pekan } \\
\mathbf{1}\end{array}$ & $\begin{array}{c}\text { Nilai } \\
\text { Pekan } \\
\mathbf{2}\end{array}$ & $\begin{array}{c}\text { Nilai } \\
\text { Pekan } \\
\mathbf{3}\end{array}$ \\
\hline 1 & Andika Rahmad & 80 & 87 & 88 \\
\hline 2 & Andre Candra & 80 & 85 & 90 \\
\hline 3 & Afrija Yanti & 80 & 85 & 90 \\
\hline 4 & Asmarina & 80 & 85 & 90 \\
\hline 5 & Anek & 80 & 85 & 90 \\
\hline 6 & Eko Purwanto & 80 & 85 & 90 \\
\hline 7 & Fikri Rinaldi & 80 & 85 & 90 \\
\hline 8 & Irvan & 80 & 85 & 90 \\
\hline 9 & Jon Fahri & 80 & 90 & 95 \\
\hline 10 & Mardwi Hendri & 80 & 85 & 90 \\
\hline 11 & Milus Solihati & 80 & 85 & 87 \\
\hline 12 & Mittoparit & 85 & 85 & 90 \\
\hline 13 & Nettiariyanti & 85 & 85 & 90 \\
\hline 14 & Novira Yulia & 85 & 90 & 90 \\
\hline 15 & Pandi Surya & 90 & 90 & 95 \\
\hline 16 & Vivin Safni & 80 & 80 & 95 \\
\hline 17 & Waliza Rahmawati & 90 & 95 \\
\hline
\end{tabular}




\begin{tabular}{|l|l|l|l|l|}
\hline 18 & Winda Rahman & 80 & 80 & 90 \\
\hline
\end{tabular}

suggestions for this application:

1. material is limited to recognizing numbers from 1 to 100, recognizing the number of units, dozens, tens and hundreds.

2. in addition material, the application only displays the sum of 10 questions only and so does the reduction.

\section{Figures AND TABLES}

\section{TABLE STYLES}

\begin{tabular}{|l|l|c|c|}
\hline \multirow{2}{*}{$\begin{array}{c}\text { Table } \\
\text { Head }\end{array}$} & \multicolumn{2}{|c|}{ Table Column Head } \\
\cline { 2 - 4 } & \multicolumn{1}{|c|}{ Table column subhead } & $\begin{array}{c}\text { Subhea } \\
\text { d }\end{array}$ & $\begin{array}{c}\text { Subh } \\
\text { ead }\end{array}$ \\
\hline Fig.3.1 & research methodology & & \\
Fig.3.2 & Use Case Diagram & & \\
Fig.3.3 & $\begin{array}{l}\text { Diagram Activity Sub number } \\
\text { addition sub menu }\end{array}$ & & \\
Fig.3.4 & Activity diagram value & & \\
Fig.3.5 & Sequence Diagram Select the & & \\
Fig.3.6 & Add Menu & & \\
Fig 3.7 & Dutput Design & & \\
Fig 3.8 & Draft Nain Menu Num Add Form & \\
Fig 3.9 & Number Recognition & \\
\hline
\end{tabular}

\section{ACKNOWLEDGMENT}

first, I say thank you to Allah SWT for giving me useful knowledge so that until now I can produce scientific work.

then salawat and greetings were given to the messenger of Allah, the prophet Muhammad SAW who brought Islam into an age full of knowledge and blessing.

\section{ConferenceIEEE}

next for family and friends of researchers who have helped in data collection

also do not forget to thank the head of the public school elementary school 014 pulau binjai for allowing us to research and apply this research, also to the math teacher at elementary school 014 pulau binjai we thank you for your help and advice in developing this application further.

\section{REFERENCES}

Roedavan Rickman Unity Tutorial Game Engine 2018 Informatika

Wibawanto wandah Memprogram Game Flash 3D itu mudah 2013ANDI.

F.Haswan and N. W. Al-Hafiz, Aplikasi Game Edukasi Ilmu Pengetahuan Alam, Vol.3, No.1, Riau Kournal Of Computer Science, 2016, pp. 31-40.

Andi Taru Nugroho NW Pemrograman Game Berbasis Web Menggunakan JavaScript + HTML 5

2012 ANDI.

Andi Taru Nugroho NW Cara Mudah Membuat Game di Android 2013, ANDI Publishing.

Kristo Radion, S.ST Easy Game Programming using Flash and Action Script 3.0 2012 ANDI.

Wahana Komputer Mudah Membuat Game 3 Dimensi Menggunakan Unity 3d 2013 ANDI.

Mukti Adi Azhari dan Agung Arnas Wibowo Membuat Game Edukasi dengan HTML5 dan Android Studio 2017 Lokomedia.

Wahana Komputer Beragam Desain Game Edukasi dengan Adobe Flash CS5 2012 ANDI.

RICKMAN ROEDAVAN Contruct 2 Tutorial Game Engine 2017 Informatika. 